\title{
Comparative evaluation of conceptual and physical rainfall-runoff models
}

\author{
R. K. Jaiswal ${ }^{1}(1) \cdot$ Sohrat Ali $^{2} \cdot$ Birendra Bharti $^{2}$
}

Received: 24 April 2019 / Accepted: 12 December 2019 / Published online: 3 January 2020

(C) The Author(s) 2020

\begin{abstract}
The design of water resource structures needs long-term runoff data which is always a problem in developing countries due to the involvement of huge cost of operation and maintenance of gauge discharge sites. Hydrological modelling provides a solution to this problem by developing relationship between different hydrological processes. In the past, several models have been propagated to model runoff using simple empirical relationships between rainfall and runoff to complex physical model using spatially distributed information and time series data of climatic variables. In the present study, an attempt has been made to compare two conceptual models including TANK and Australian water balance model (AWBM) and a physically distributed but lumped on HRUs scale SWAT model for Tandula basin of Chhattisgarh (India). The daily data of reservoirs levels, evaporation, seepage and releases were used in a water balance model to compute runoff from the catchment for the period of 24 years from 1991 to 2014. The rainfall runoff library (RRL) tool was used to set up TANK model and AWBM using auto and genetic algorithm, respectively, and SWAT model with SWATCUP application using sequential uncertainty fitting as optimization techniques. Several tests for goodness of fit have been applied to compare the performance of conceptual and semi-distributed physical models. The analysis suggested that TANK model of RRL performed most appropriately among all the models applied in the analysis; however, SWAT model having spatial and climatic data can be used for impact assessment of change due to climate and land use in the basin.
\end{abstract}

Keywords Rainfall runoff model $\cdot$ Optimization $\cdot$ Water balance $\cdot$ Conceptual model $\cdot$ Physical model

\section{Introduction}

The rainfall-runoff modelling is an important and useful tool for hydrological research, water engineering and environment application. The runoff computation from ungauged or poorly gauged catchments is a serious challenge in developing countries like India where higher operation and maintenance cost differed gauging on small and medium rivers. The knowledge-based or data-driven hydrological models were developed and used by researchers to extend runoff records and address modelling issues (Kar et al. 2015, 2017). The hydrological model can be classified into three broad groups, namely metric, physical and conceptual models (Beck et al.

$\triangle$ R. K. Jaiswal

rkjaiswal.nih@gmail.com

1 CIHRC, National Institute of Hydrology, WALMI Campus, Bhopal, M.P., India

2 Centre for Water Engineering and Management, Central University of Jharkhand, Ranchi, Jharkhand, India
1990). The rainfall-runoff relationships in metric models are essentially based on observations and without characterizing different processes involved in the hydrologic system (Kokkonen and Jakeman 2001). The linearity assumptionbased unit hydrograph theory (Sherman 1932), catchment characteristics-based rational formula for peak runoff given by JM Thomas (1822-1892) and reproduced by Loague (2010), Strange tables, etc., are some of the examples of metric modelling. The metric models are observation-based models developed using observed runoff and catchment characteristics without considering much of hydrological processes. The physical models represent different hydrological processes through mass, momentum and energy conservation equations. The physical models may be capable of considering the spatial variability of land use, slope, soil and climate to deal with the hydrological processes within the watershed semi- or fully distributed in nature.

The conceptual models are hydrological models that use simplified mathematical conceptualization of a system with the help of a number of interconnected storages used to

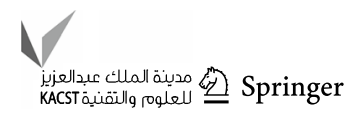


represent different components of the hydrological process through recharge and depletion. The conceptual models are usually lumped in nature and use the same value of parameters for the whole watershed and ignored the spatial variability of watershed characteristics. The conceptual models strongly rely on observed data, and results depend on the quality of input data used in the model. Large numbers of conceptual models have been proposed in the past including Sacramento model (Brazil and Hudlow 1981), Clark model (Clark 1945), Nash model (Nash 1957), HBV model (Bergstrom 1992, 1995), HYMOD (Moore 1985), watershed model (Crawford and Linsley 1966), TANK model (Sugawara et al. 1974, 1983), Boughton (1984) model, MODHYDROLOG (Chiew and McMahon 1994), HEC-1 (Burnash et al. 1973), Xinanjiang model (Zhao and Liu 1995), ARNO model (Todini 1996), etc.

The physical models represent different hydrological processes through mass, momentum and energy conservation equations. The finite difference or finite computation schemes are generally used to solve governing partial difference equations in these models. The physical models may be capable of considering the spatial variability of land use, slope, soil and climate to deal with the hydrological processes within the watershed semi- or fully distributed in nature. As physical models are distributed in nature, they require large amount of topographical, soil, land use and climatic data to provide a framework to explore the changes in hydrological cycle due to human interferences and climate change for water resources management (Leavesley 1994; Jiang et al. 2007; Yang et al. 2008, 2014; Praskievicz and Chang 2009, Wang et al. 2010; Chen et al. 2016). At the same time, these models can depict complex hydrological processes and predict different components of the hydrological cycle with an acceptable limit of efficiency. The TOPMODEL (Beven and Kirkby 1976, 1979; Beven et al. 1995), SHE (Abbott et al. 1986a, b), ISBA (Nolihan and Planton 1989; Nolihan and Mahfouf 1996), SLURP (Kite 1995), MIKE SHE (Refsgaard and Storm 1995); SWAT (Arnold et al. 1998a, b), DPHM-RS (Biftu and Gan 2001, 2004); TOPNET (Bandaragoda et al. 2004), MISBA (Kerkhoven and Gan 2006), HydroGeoSphere (Therrien et al. 2006), PIHM (Qu and Duffy 2007), CATFLOW (Zehe et al. 2005; Klaus and Zehe 2010), CREST (Wang et al. 2011), variable infiltration capacity (VIC) (Wood et al. 1992; Liang et al. 1994; Lohmann et al. 1998) models are some of the most commonly used semi- or fully distributed physical models. The comparison of conceptual and physical models is presented in Table 1.

Vaze et al. (2012) have analysed strength and weakness of different types of models and concluded that metric and conceptual models are suited for daily timescale while physical models can be used on daily as well as the sub-daily timescale. The requirement of high-resolution spatial and other data is low for metric models, moderate for the conceptual model, while high to very high in case of semi-distributed and fully distributed physical models. Similarly, metric models may have 1 to 5 parameters; conceptual models may have 4 to 20 parameters, while fully distributed models can have 10 to 1000 parameters to be adjusted for calibration. Haque et al. (2015) have quantified different uncertainties of rainfall-runoff modelling with AWBM in a gauged catchment and an ungauged catchment. In the study, five rainfall data sets, twenty-three different calibration data length and eight optimization techniques for gauge catchment have been employed and extended to the ungauged catchment using two regional prediction equations. The uncertainties were compared with observed and model runoff by the AWBM and varied from $1.3 \%$ to $70 \%$ in input rainfall data, 5.7\% to $11 \%$ in calibration and $6 \%$ to $0.2 \%$ in optimization technique. Zhang et al. (2016) have applied the Australia water balance model (AWBM) and simple multiple regression to model stream flows in five tributaries of the Poyang Lake basin. The results indicated that multiple regression models were appropriate with precipitation, and potential evapotranspiration of the current month and precipitation of the last month were explanatory variables, but AWBM gave higher Nash-Sutcliffe efficiency.

Kumar et al. (2015) discussed the application of different conceptual and semi-distributed model for application in a basin which used different kinds of model parameter and input data. In order to select the best model, MIKE SHE, SWAT, HEC-HMS, AWBM, SIMHYD, Sacramento, SMAR and TANK models along with linear programming (LP) were used, and it was found that an ensemble exhibited comparative results with the order of SWAT, AWBM, HEC-HMS, SIMHYD and Sacramento for the performance

Table 1 Comparison of conceptual and physical models

\begin{tabular}{lll}
\hline Comparison & Conceptual models & Physical model \\
\hline Method & Simplified equation to represent water represent storage & Physical laws and equations based on real hydrological response \\
Strength & Easy to calibrate, simple model structure & Incorporates spatial and temporal variabilities; fine scale is possible \\
Weakness & Does not consider spatial variability within catchment & Large number of parameters and calibration needed; site specific \\
Best use & When computation time or data are limited & Have great data availability on a small scale \\
Example & Clark, TANK, AWBM, Xinanjiang, NAM & MIKE SHE, SWAT, KINEROS, VIC \\
\hline
\end{tabular}


on a selected catchment. Shoaib et al. (2018) discussed that rainfall-runoff modelling through a stochastic process which depends on climatologically variable and catchment characteristic. Onyutha (2016) applied five conceptual hydrological models including AWBM, TANK, SIMHYD, Sacramento and IHACRES in Blue Nile basin for rainfall-runoff simulation. The Nash-Sutcliffe efficiency was used as a goodnessof-fit measure for selecting the best model. They suggested that the choice of model should be made on the basis of the objective of modelling.

The SWAT model has several tools; interfaces and supporting software have been developed in the last 20 years making this software more versatile. The latest developed SWAT-CUP has the capability of sensitivity and several optimization techniques like GLUE, Parasol, SUFI2, MCMC and PSO. The main weakness of the model is the requirement of a wide range of data and non-spatial representation of the HRU inside each sub-catchment. Glavan and Pinter (2012) described strength, weakness, opportunities and threat (SWOT) of SWAT model and described the strength of SWAT model as an easily available online model that can combine water quality, quantity, agriculture land management, and climate change simultaneously. Khoi and Thom (2015) have applied SWAT model and SWAT-CUP application using generalized likelihood uncertainty estimation (GLUE), parameter solution (Parasol), particle swarm optimization (PSO) and sequential uncertainty fitting (SUFI2) techniques for uncertainty analysis in the catchment of river Srepok of Vietnam. The results of the analysis indicated that among all the methods, SUFI2 may be the most suitable method as it required the smallest runs to get appreciable prediction and model performance. Similarly, several other researchers have compared different techniques of optimization and uncertainty for SWAT model and found SUFI 2 can predict the runoff reasonably well with the smaller number of simulations (Wu and Chen 2015; Uniyal et al. 2015; Mamo and Jain 2013).

Looking into the strength and weakness of different conceptual and semi-distributed physical models, the present study deals with the comparative evaluation of some conceptual and distribute models for performance in an Indian basin having problems of availability of data.

\section{Material and methodology}

\section{Study area}

The study area for the present study is Tandula catchment up to Tandula reservoir in the Chhattisgarh state of India. Tandula reservoir is situated on the confluence of river Tandula with Sukha Nala in Balod district having a catchment area of $827.2 \mathrm{~km}^{2}$. The location map of the study area has been presented in Fig. 1. The Tandula dam has been constructed in the year 1921 and presently irrigating 82,095 ha paddy fields along with the supply of industrial water to Bhilai Steel Plant at Durg and other domestic supplies to several tanks in the command. The Tandula catchment is influenced by four rain gauge stations including Balod, Bhanpura, Chamra and Gondli in and around the catchment with the Thiessen weight of $0.18,0.39,0.25$ and 0.18 , respectively.

\section{Data used}

The daily reservoir level, releases and overflow from weir for the period from 1991 to 2015 have been used in a simple water balance model to compute daily runoff from the catchment. The rainfall data of Balod, Bhanpura, Chamra and Gondli and climatic data of Raipur have been used in the analysis. The land use of the study area has been determined using multiple LISS III data from IRS satellite. The climatic data of Raipur climatic station were used in rainfall-runoff modelling. The soils have been identified from literature review and maps from All India Soil Survey \& Land Use Planning (AISSLUP, Nagpur).

\section{Methodology}

In the study, two conceptual models (TANK model and AWBM ) available in Rainfall Runoff Library (RRL) and developed by Co-operative Research Centre for Catchment Hydrology $(\mathrm{CRCCH})$, Australia and a semi-distributed model (Soil and Water Analysis Tool) have been evaluated for their performance in Tandula basin of India. The RRL was developed using practical experience of $\mathrm{CRCCH}$ research and freely available on http://www.toolkit.net. $\mathrm{au} /$ Tools/RRL. The RRL library is capable of modelling hydrological processes in the catchment using models such as AWBM, Sacramento, SIMHYD, SMAR and TANK. The parameters of these models can be optimized using any one of the techniques including uniform random sampling, genetic algorithm (GA), shuffled complex evaluation (SECUA), pattern search, multi-start pattern search, Rosenbrock search and Rosenbrock multi-start search. The calibration and validation of these models can be done with any one of ten different objective functions including Nash-Sutcliffe efficiency (Nash and Sutcliffe 1970), sum of square error, root-mean-square error, root-mean-square difference about bias, absolute value of bias, sum of square roots, sum of square of the difference of square root and sum of absolute difference of the log-transformed data. The SWAT is a semi-distributed physical model capable of modelling hydrological processes including quantity, quality and sediment in a basin. The SWAT model is a widely used model for 


\section{Comparative Evaluation of Conceptual and Physically based Rainfall- \\ Runoff Models}

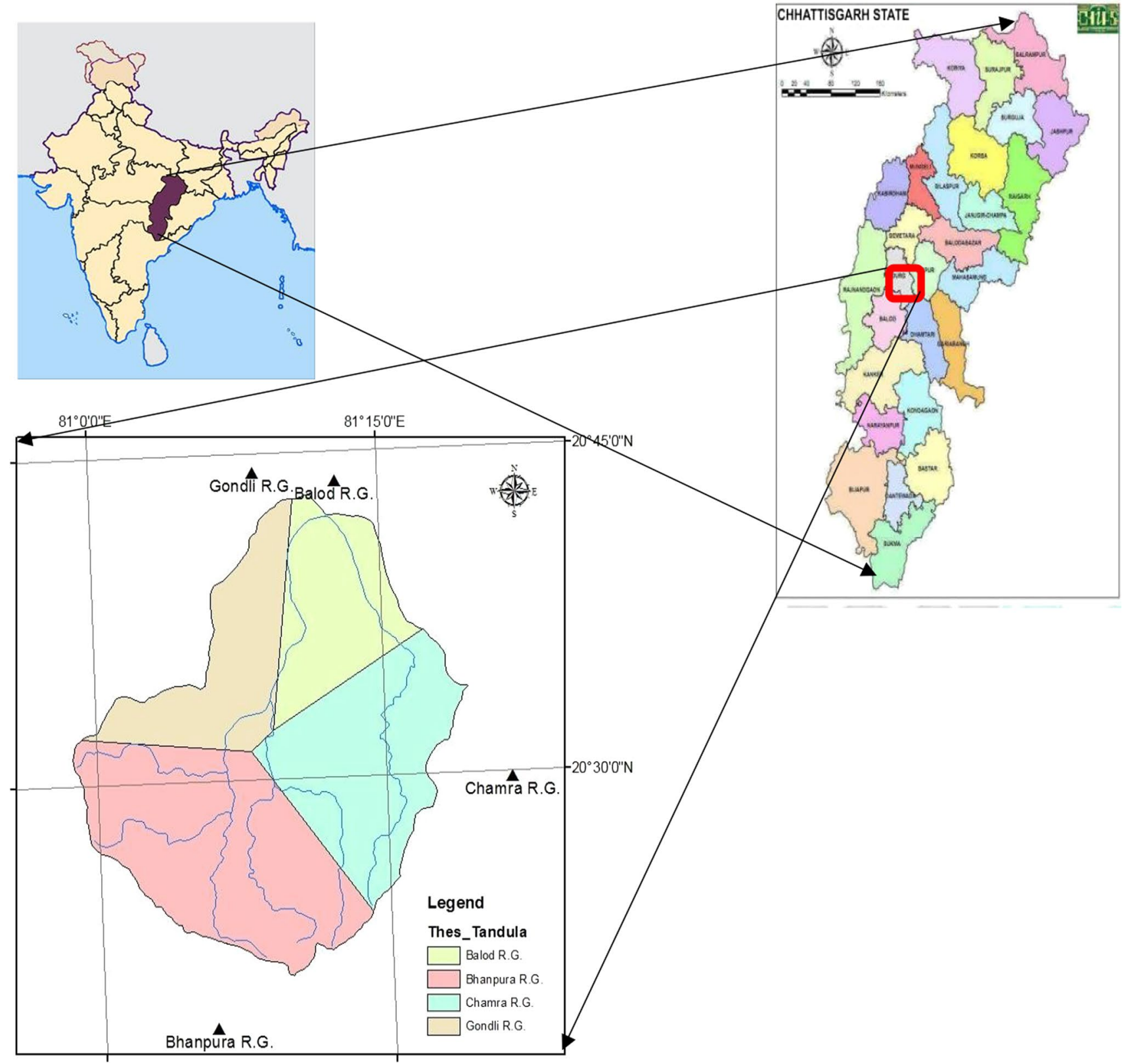

Fig. 1 Location map of Tandula catchment in Chhattisgarh state of India

runoff, recharge, sediment and nutrient flow in the basin. The description of TANK, AWBM and SWAT applied in the analysis is presented below.

\section{TANK model}

The TANK model in RRL consists of four vertical tanks in series where precipitation and evaporation are used as inputs in the top tank and evaporation is subtracted sequentially from all the tanks. In this model, the top tank has two outlets, while all other tanks have only one outlet with runoff coefficient $a_{x y}$ at variable heights $H_{x y}$. Here, $x$ is the number of tank and $y$ is the number of outlets (Fig. 2). The total runoff is computed as the sum of runoff from all the tanks using the following equation:

$q=\sum_{x=1}^{4} \sum_{y=1}^{n x}\left(C_{x}-H_{x y}\right) a_{x y}$ 


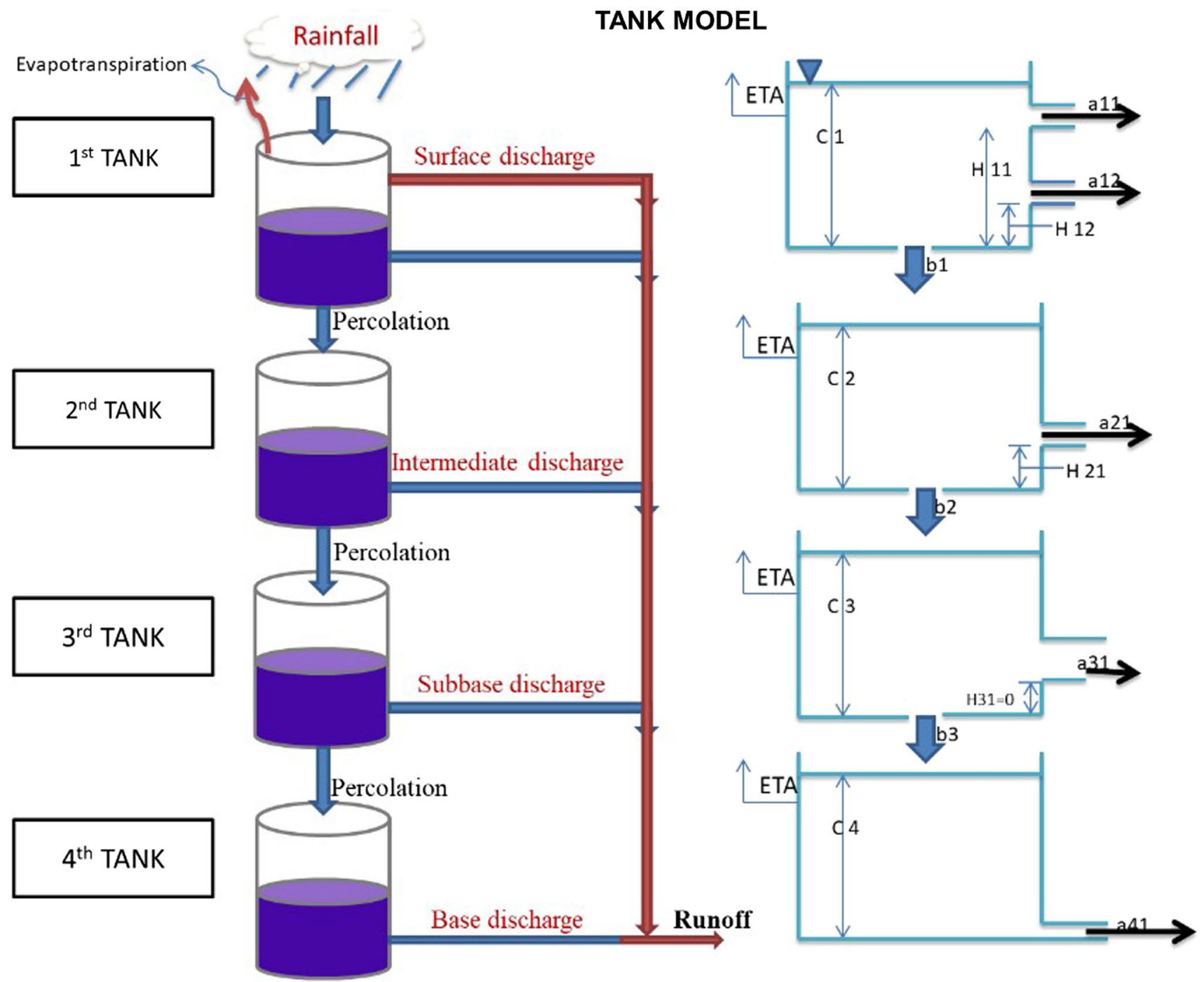

Fig. 2 Structure of TANK Model in RRL. (Reproduced from RRL manual)

where $q$ is the runoff in $\mathrm{mm}, C_{x}$ is the level of water in the $x$ th tank, $H_{x y}$ is the height of the $y$ th outlet in the $x$ th tank. The actual evapotranspiration (ETA) from each tank is the loss from the system and can be computed based on the depth of water $\left(C_{x}\right)$ in $x$ th tank. The following equation can be used to compute actual evapotranspiration (ETA) for a tank.

$\operatorname{ETA}=\operatorname{ETP}\left(1-\mathrm{e}^{-\propto \sum C_{x}}\right)$

The infiltration $\left(I_{x}\right)$ in these tanks can be computed using tank-wise infiltration coefficient $\left(b_{x}\right)$ and water levels in the corresponding tank with the help of the following equation:

$I_{x}=C_{x} b_{x}$
The sum of runoff computed from different tanks can be considered as total runoff from the basin. The first tank gives surface runoff, second tank intermediate runoff, while third and fourth tanks provide sub-base and base flow, respectively. The different parameters, their default value and range of TANK model have been presented in Table 2.

\section{AWBM model}

The AWBM works on the basis of three independent surface storages for computation of partial runoff from a catchment (Fig. 3). The model independently calculates water balance for each surface storage using precipitation and evapotranspiration as inputs. The whole catchment in this model can be divided into three partial areas using three parameters as $A_{1}, A_{2}$ and $A_{3}$. The soil moisture for each partial area is 
Table 2 Range and default values of parameter in TANK model

\begin{tabular}{llll}
\hline Parameter & Default value & Range \\
\cline { 3 - 4 } & & Minimum & Maximum \\
\hline Height of first outlet of first tank in mm $\left(H_{11}\right)$ & 0 & 0 & 500 \\
Height of second outlet of first tank in mm $\left(H_{12}\right)$ & 0 & 0 & 300 \\
Height of first outlet of second, third and fourth tanks in & 0 & 0 & 100 \\
$\quad$ mm $\left(H_{21}, H_{31}\right.$ and $\left.H_{41}\right)$ & & 0 & 1 \\
Runoff coefficient from outlets of different tanks $\left(a_{11}, a_{12}\right.$, & 0.2 & & 1 \\
$\quad a_{21}, a_{31}$ and $\left.a_{41}\right)$ & & 0 & 1 \\
Evaporation coefficient $(\alpha)$ & 0.1 & 100 \\
Infiltration coefficient in top three tanks $\left(b_{1}, b_{2}\right.$ and $\left.b_{3}\right)$ & 0.2 & 0 & 1 \\
Water level in the tanks in mm $\left(C_{1}, C_{2}, C_{3}\right.$ and $\left.C_{4}\right)$ & 20 & & \\
\hline
\end{tabular}

Fig. 3 Structure of AWBM in RRL. (Reproduced from RRL manual)

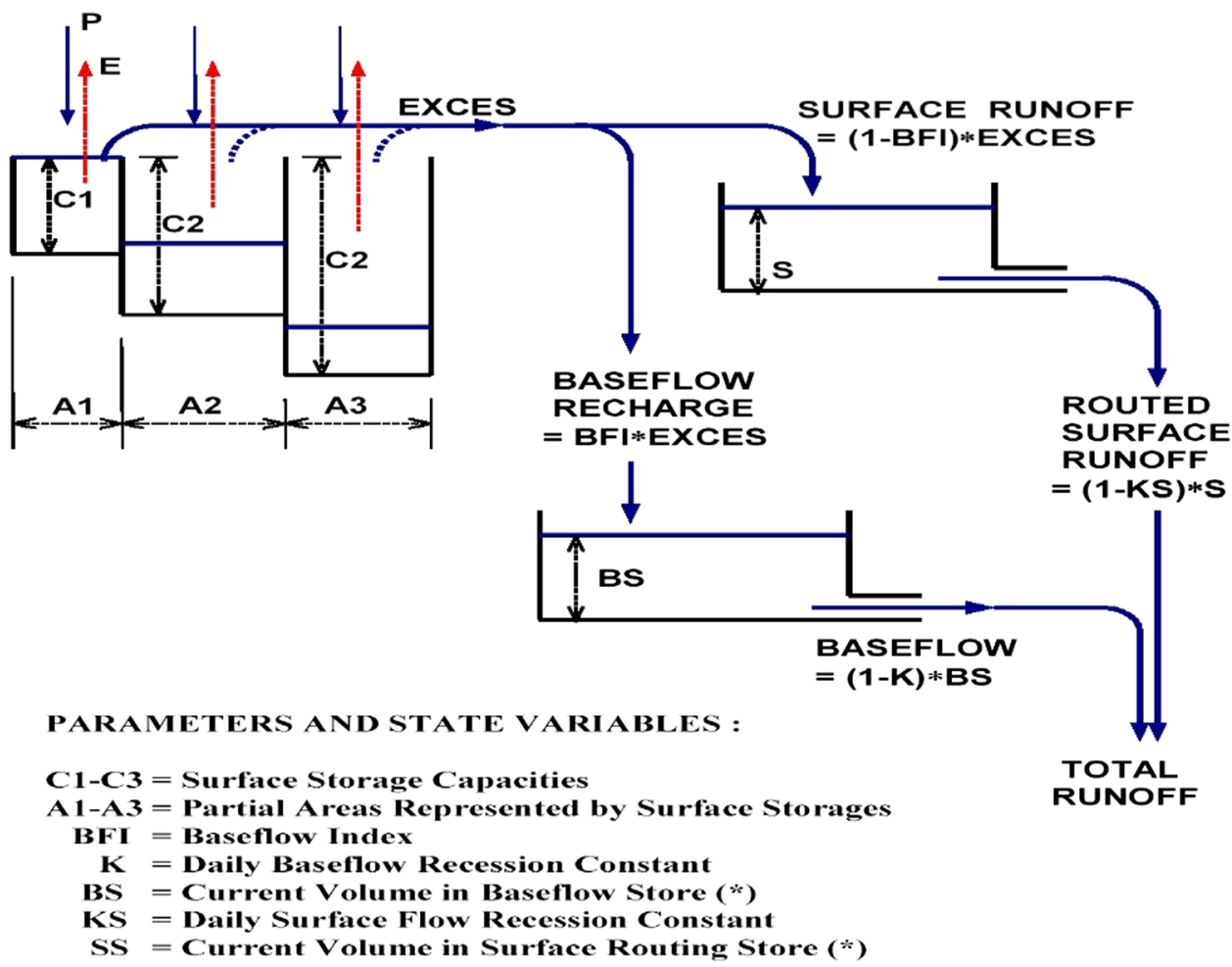

computed by adding precipitation and deducting evapotranspiration. At any time, rainfall is added to each of the partial area or storage and after deducting evapotranspiration, the following water balance equation is used to compute storage and if the moisture becomes greater than the capacity of storage, the moisture in excess of capacity becomes runoff.

$S_{n}=S_{n-1}+P_{n}-\mathrm{EVT}_{n}$

where $S_{n-1}$ and $S_{n}$ are the storage on $n-1$ and $n$th days, $P_{n}$ and $\mathrm{EVT}_{n}$ are the precipitation and evapotranspiration on $n$th day. In this model, friction $\left(\mathrm{BF}_{1}\right)$ of runoff in any partial storage gave base flow and reminder may provide surface runoff from that store using following equations.
$\mathrm{BS}_{t}=\operatorname{excess} * \mathrm{BF}_{1}$

$\mathrm{SS}_{t}=$ runoff $*\left(1-\mathrm{BF}_{1}\right)$

Both the surface runoff from three partial storage and base flow are depleted on daily or hourly timescale with the help of surface flow recession coefficient (KS) and baseflow recession coefficient $(K)$ in a linear manner using the following equations:

$\mathrm{SS}_{t}=\left(1-K_{\mathrm{S}}\right) \mathrm{SS}_{t-1}$

$\mathrm{BS}_{t}=\left(1-K_{\mathrm{B}}\right) \mathrm{BS}_{t-1}$ 
Table 3 Range and default values of parameters in AWBM

\begin{tabular}{llll}
\hline Parameter & Default value & \multicolumn{2}{l}{ Range } \\
\cline { 3 - 4 } & & Minimum & Maximum \\
\hline Partial area of first storage $\left(A_{1}\right)$ & 0.134 & 0 & 1 \\
Partial area of second storage $\left(A_{2}\right)$ & 0.433 & 0 & 1 \\
Partial area of second storage $\left(A_{3}\right)$ & $1-A_{1}-A_{2}$ & 0 & 1 \\
Base flow index $\left(\mathrm{BF}_{1}\right)$ & 0.350 & 0 & 1 \\
Storage capacity of first store $\left(C_{1}\right)$ & 7 & 0 & 50 \\
Storage capacity of second store $\left(C_{2}\right)$ & 70 & 0 & 200 \\
Storage capacity of third store $\left(C_{3}\right)$ & 150 & 0 & 500 \\
Surface flow recession coefficient $\left(K_{\mathrm{s}}\right)$ & 0.35 & 0 & 1 \\
Base flow recession coefficient $\left(K_{\mathrm{B}}\right)$ & 0.95 & 0 & 1
\end{tabular}

The routed surface and base flow at the outlet of the basin provide total runoff from the basin. The different parameters of AWBM along with the range are given in Table 3 .

\section{SWAT model}

The SWAT model (Arnold et al. 1998a, b; Neitsch et al. 2001, 2002) is a physically distributed parameter and continuous time simulation basin scale supported by USDA Agricultural Research Service (USDA-ARS) at the Grassland, Soil and Water Research Laboratory, Texas, developed to predict the response to natural inputs as well as the manmade interventions and management practices such as fertilizer application, livestock grazing and harvesting operation on water, sediment and agriculture chemical yields in gauged as well as ungauged catchments. The model works on daily/ sub-daily time step, able to simulate land management and runoff processes using spatial distribution of land use, soil and topography by dividing basin into sub-basins and hydrological response units (HRUs). Each sub-basin in the SWAT model may have an organization of climate, HRUs, ponds/ wetlands, groundwater and main channel/reach draining the basin. The land use, soil, digital elevation model, climatic data are the prime input for the model, and it is able to predict sub-basin-wise runoff, groundwater contribution, base flow, crop growth, soil erosion, sediment yield, nutrient status, etc. (Santhi et al. 2006).

The runoff volume in the SWAT model is estimated by Soil Conservation Services (SCS) curve number technique. The runoff yield for individual HRU and then for sub-watersheds are routed through river network using variable storage or Muskingum routing method. The complete detail about the SWAT model and its application are available in Neitsch et al. (2001, 2005). The model have hundreds of parameters for defining the spatial variability of hydrological characteristics of the basin, out of which some of the parameters vary by sub-basin, land use, or soil type, while others can be computed through field measurement, data or literature. The SWAT model works on the principle of water balance, and two major components of the hydrological cycle are computed considering physical process within the basin. The first phase computes the runoff, sediment, nutrients and pesticide loading to the main channel of each basin, while the second phase concentrates on routing for movement of generated runoff, sediment, nutrient and pesticide through a network of the channel to the outlet of the basin. The different components of the hydrological cycle in the SWAT model can be represented by the following water balance equation:

$\mathrm{SW}_{i}=\mathrm{SW}_{0}+\sum_{i=1}^{t}\left(P_{i}-\mathrm{SQ}_{i}-\mathrm{ET}_{i}-W_{\text {seep }}-Q g w_{i}\right)$

where $\mathrm{SW}_{o}$ and $\mathrm{SW}_{i}$ are the soil water content in $\mathrm{mm}$ of $\mathrm{H}_{2} \mathrm{O}$ at initial and $t$ th day, respectively, $P_{i}, \mathrm{SQ}_{i}, \mathrm{ET}_{i}, W_{\text {seep }}$ and $Q g w_{i}$ are the precipitation, surface runoff, evapotranspiration, water enter into the vadose zone and return flow in terms $\mathrm{mm}$ of $\mathrm{H}_{2} \mathrm{O}$ on the $i$ th day, respectively. The runoff computed for each HRU is routed to get total runoff at the outlet of the basin. The SWAT model has options for computation of surface runoff either using modified SCS curve number method or Green and Ampt method. The input precipitation in the model first undergoes interception and is computed by the canopy in the SCS curve number method or user-defined leaf area index in case of Green and Ampt method. The infiltration in the SWAT model can be computed either directly through Green and Ampt method or by the remaining amount of water from precipitation after generation of daily runoff in case of SCS method. The following formulae are used to predict surface runoff using the SCS-CN method.

$Q=\frac{\left(P-I_{\mathrm{a}}\right)^{2}}{\left(P-I_{\mathrm{a}}+S\right)}$

where $I_{\mathrm{a}}=0.2 S$ for antecedent moisture condition II (AMC II), $Q$ is the surface runoff in $\mathrm{mm}, P$ is the rainfall in $\mathrm{mm}, I_{\mathrm{a}}$ is the initial abstraction, $S$ is the surface retention and can be computed by the following equation. 
$S=\frac{25400}{C N}-254$

where $\mathrm{CN}$ is the curve number depends on soil type, land use, management practices and antecedent moisture condition. The $\mathrm{CN}$ values as defined in SCS method are used in the model and modified for antecedent moisture condition I (dry condition), II (average condition) or III (wet condition) in the model. For computation of evaporation from soil and water separately, the method suggested by Ritchie (1972) is used, while the options of Hargreaves method (Hargreaves et al. 1985), Priestley-Taylor method (Priestley and Taylor 1972) and Penman-Monteith method (Monteith 1965) are available for computation of potential evapotranspiration. The water percolated to the bottom root zone is partitioned in interflow and baseflow. The lateral subsurface flows or interflow is computed using a kinematic storage model in each soil layer, while baseflow or groundwater is muddled using two aquifer systems in the SWAT model. The topmost aquifer which is considered as unconfined aquifer contributes return flow within the watershed, and underlined deep aquifer contributes outside of the watershed (Arnold et al. 1993). The baseflow is only allowed when the amount of water stored in shallow aquifer reached to a prescribed level defined by the user and then baseflow which is the contribution to the main channel or reach is computed using the study-state response of groundwater flow suggested by Hooghoudt (1940).

\section{Comparative evaluation of performance}

The application of models whether simple or complex depends on how well they can reproduce the response of the system. The Nash-Sutcliffe efficiency (NS), the coefficient of correlation $\left(C_{\mathrm{c}}\right)$ and root-mean-square error (RMSE) were used as the goodness-of-fit criterions for selecting an appropriate model.

\section{Results and discussion}

The RRL library has been used to set up conceptual models like TANK model and AWBM, while the SWAT model in Arc GIS and SWAT-CUP application have been employed as a physical model for Tandula basin. Before carrying out modelling, a daily water balance of Tandula reservoir has been carried out for computation of runoff for the period of 25 years from the year 1991 to 2015 and used as input to these models. The results of the application of AWBM, TANK model and SWAT model are presented below.

\section{Conceptual models}

\section{TANK model}

The aerial rainfall series based on Thiessen weight of different stations and evapotranspiration computed from climatic data of Raipur station were used as inputs to the TANK model where data from 1991 to 1994 have been used for warming, 1995 to 2004 for calibration and
Table 4 Calibrated value and range of parameters of TANK model

\begin{tabular}{llll}
\hline S.N. & Description of parameter & Optimized value & Parameter range \\
\hline 1 & Height of first outlet of first tank $\left(h_{11}\right)$ & 356.86 & $0-500$ \\
2 & Height of second outlet of first tank $\left(h_{12}\right)$ & 182.35 & $0-300$ \\
3 & Height of first outlet of second tank $\left(h_{21}\right)$ & 10.19 & $0-100$ \\
4 & Height of first outlet of third tank $\left(h_{31}\right)$ & 81.5 & $0-100$ \\
5 & Outlet height of fourth tank $\left(h_{41}\right)$ & 16.86 & $0-100$ \\
6 & Runoff coefficient of first outlet of first tank $\left(a_{11}\right)$ & 0.536 & $0-1.0$ \\
7 & Runoff coefficient of second outlet of first tank $\left(a_{12}\right)$ & 0.011 & $0-1.0$ \\
8 & Runoff coefficient of second tank $\left(a_{21}\right)$ & 0.7 & $0-1.0$ \\
9 & Runoff coefficient of third tank $\left(a_{31}\right)$ & 0.19 & $0-1.0$ \\
10 & Runoff coefficient of fourth tank $\left(a_{41}\right)$ & 0 & $0-1.0$ \\
11 & Evapotranspiration coefficient $(\alpha)$ & 3.96 & $0-5$ \\
12 & Infiltration coefficient of tank $\left(b_{1}\right)$ & 0.027 & $0-1.0$ \\
13 & Infiltration coefficient of tank $\left(b_{2}\right)$ & 0.298 & $0-1.0$ \\
14 & $b_{3}\left(\right.$ Infiltration coefficient of tank $\left(b_{3}\right)$ & 0.63 & $0-1.0$ \\
15 & Water level of tank $1\left(C_{1}\right)$ & 64.3 & $0-100$ \\
16 & Water level of tank $\left(C_{2}\right)$ & 20 & $0-100$ \\
17 & Water level of tank $\left(C_{3}\right)$ & 61.56 & $0-100$ \\
18 & Water level of tank $\left(C_{4}\right)$ & 23.9 & $0-100$ \\
\hline
\end{tabular}


2005 to 2015 for validation of the model. The auto-calibration has been done for optimization of parameters of the model, and then, genetic algorithm (GA) has been used to get further refined values of parameters. The optimized parameters of TANK model have been presented in Table 4. The graphical representation of observed and computed runoff obtained from TANK models during calibration and validation has been presented in Fig. 4. The Nash-Sutcliffe efficiency of the model during calibration and validation was found as 0.84 and 0.81 , respectively, and can be considered as a very good match (Moriasi et al. 2007).

\section{AWBM model}

Similar to the TANK model, the AWBM has been set up in RRL toolkit. The model warming, calibration and validation of the model have been carried out for the periods of 1991-1994, 1995 to 2004 and 2005 to 2015, respectively. The calibration of the parameters of the AWBM was done

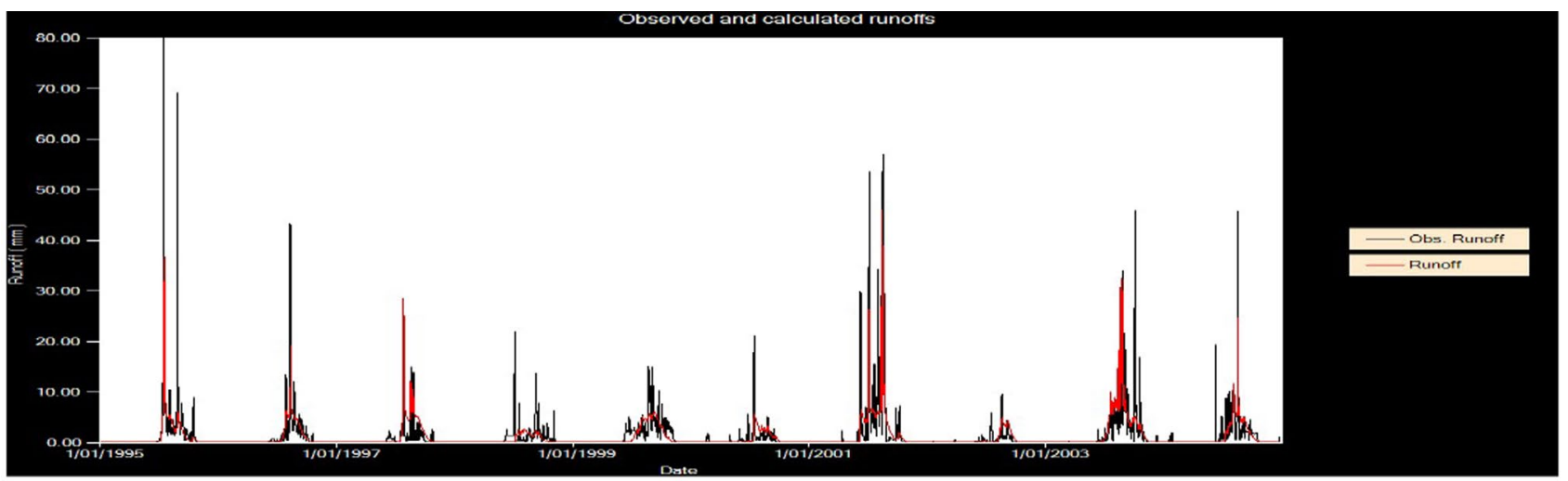

(a) Calibration

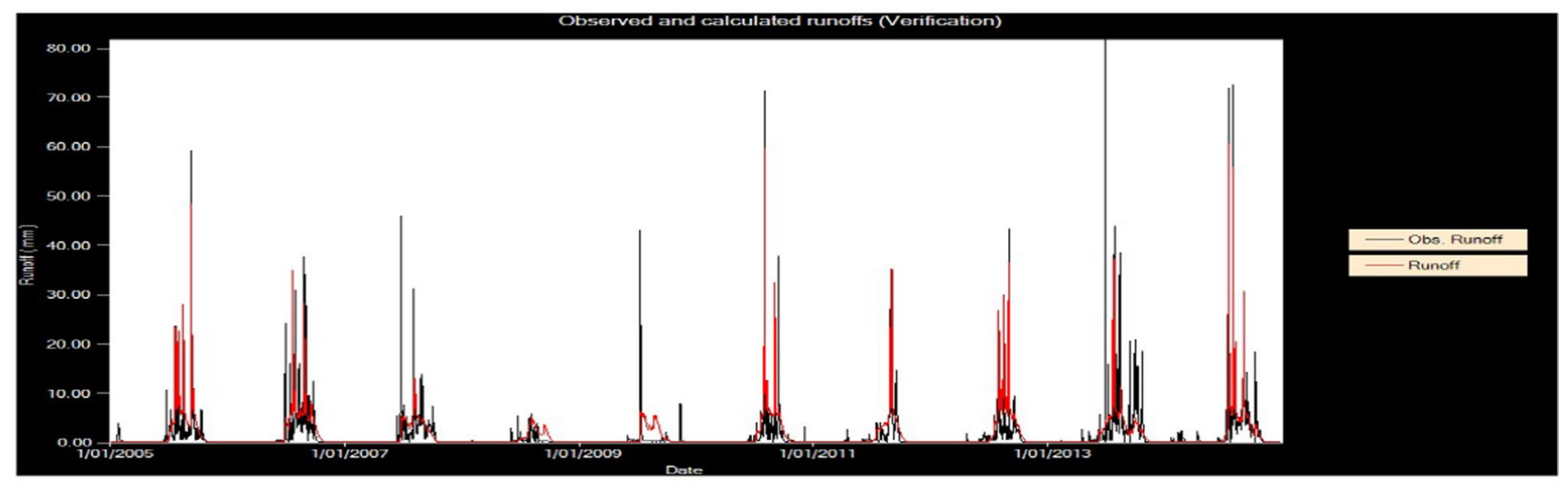

(b) Validation

Fig. 4 Observed and simulated runoff from TANK model

Table 5 Calibrated value and range of parameters of AWBM

\begin{tabular}{llcc}
\hline S.N. & Description of parameter & Optimized value & Parameter range \\
\hline 1 & Partial area of first storage $\left(A_{1}\right)$ & 0.134 & $0.000-1.000$ \\
2 & Partial area of second storage $\left(A_{2}\right)$ & 0.433 & $0.000-1.000$ \\
3 & Partial area of second storage $\left(A_{3}\right)$ & 0.433 & $0.000-1.000$ \\
4 & Base flow index $\left(\mathrm{BF}_{1}\right)$ & 0.501 & $0.000-1.000$ \\
5 & Storage capacity of first store $\left(C_{1}\right)$ & 7.25 & $0-50$ \\
6 & Storage capacity of second store $\left(C_{2}\right)$ & 185.88 & $0-200$ \\
7 & Storage capacity of third store $\left(C_{3}\right)$ & 496.07 & $0-500$ \\
8 & Surface flow recession coefficient $\left(K_{\mathrm{S}}\right)$ & 01 & $0.000-1.000$ \\
9 & Base flow recession coefficient $\left(K_{\mathrm{B}}\right)$ & 0.94 & $0.000-1.000$ \\
\hline
\end{tabular}


initially by auto-calibration and then genetic algorithm to optimize the parameters. The calibrated values of different parameters of AWBM in RRL are presented in Table 5. The observed and computed runoff from the optimized AWBM are plotted and presented in Fig. 5 and found an acceptable match. The Nash-Sutcliffe efficiency of the model was worked out as 0.76 and 0.79 , respectively, and can be considered as the good match on a daily scale.

\section{SWAT model}

In the study, SWAT which is a semi-distributed physical model has been established using digital elevation model, land use and soil maps of Tandula catchment (Fig. 6). The ASTER DEM has been used for delineation of the Tandula watershed and 12 sub-watersheds in the basin. The land uses have been divided into five groups namely deciduous forest (FRSD), low density urban (URLD), scrub (RNGB), agriculture (RICE) and water body (WATR). The soil map of the study area has been derived from the state soil map of National Bureau of Soil Survey \& Land Use Planning, Nagpur (India) prepared for Chhattisgarh state and literature survey (Tamgadge et al. 2002).

From the analysis, it has been found that deciduous forest covers nearly $60 \%$ catchment of Tandula reservoir and soil is mainly of loamy in nature. After setting up of the model and writing the default values of all the parameters, a simulation run of the model has been made and exported to SWAT-CUP application for sensitivity, calibration and validation.

The sensitivity analysis has been carried out using t-stat (larger absolute value) and $P$ value (smaller absolute value). The results of this analysis suggested that SCS curve number (r_CN2), saturated hydraulic conductivity (sol_k), soil antecedent water content (sol_AWC), Manning's N for main channel (ch_N2), base flow alpha factor (Alpha_BF), soil evaporation compensation factor (ESCO) and threshold depth of water in the shallow aquifer required for return flow to occur (GWQMN) are the most sensitive parameters for Tandula reservoir catchment. The test statistics of uncertainty analysis along with best-fit value and ranges of different sensitive parameters have been depicted in Table 6.

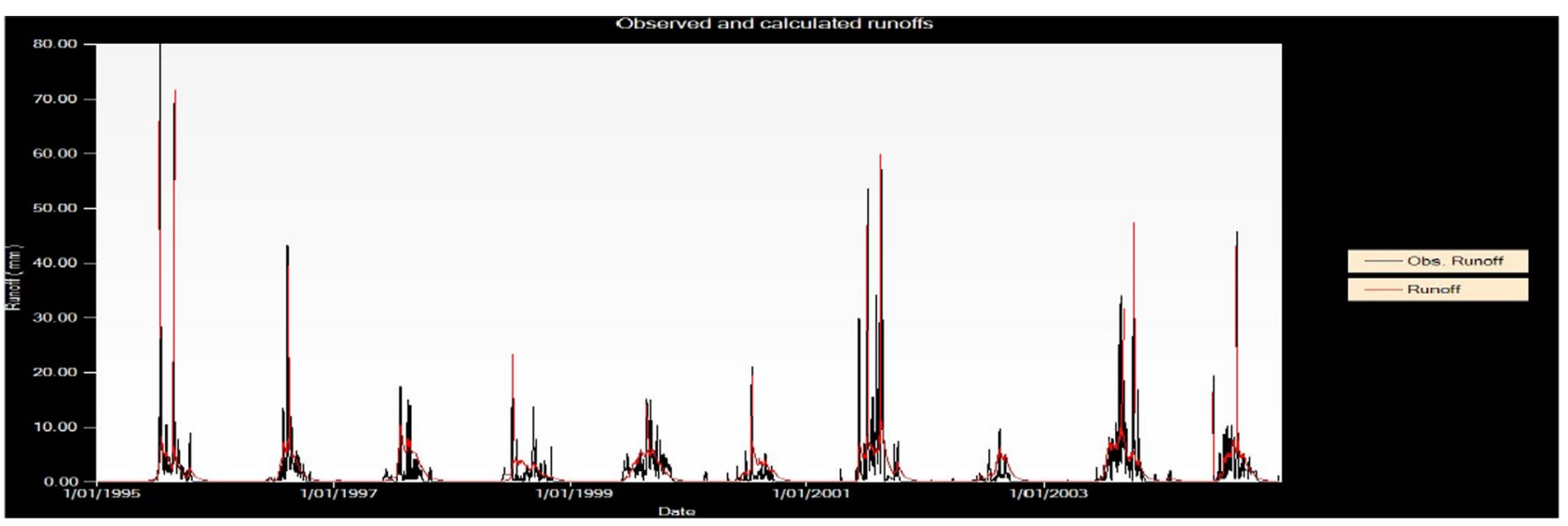

(a) Calibration

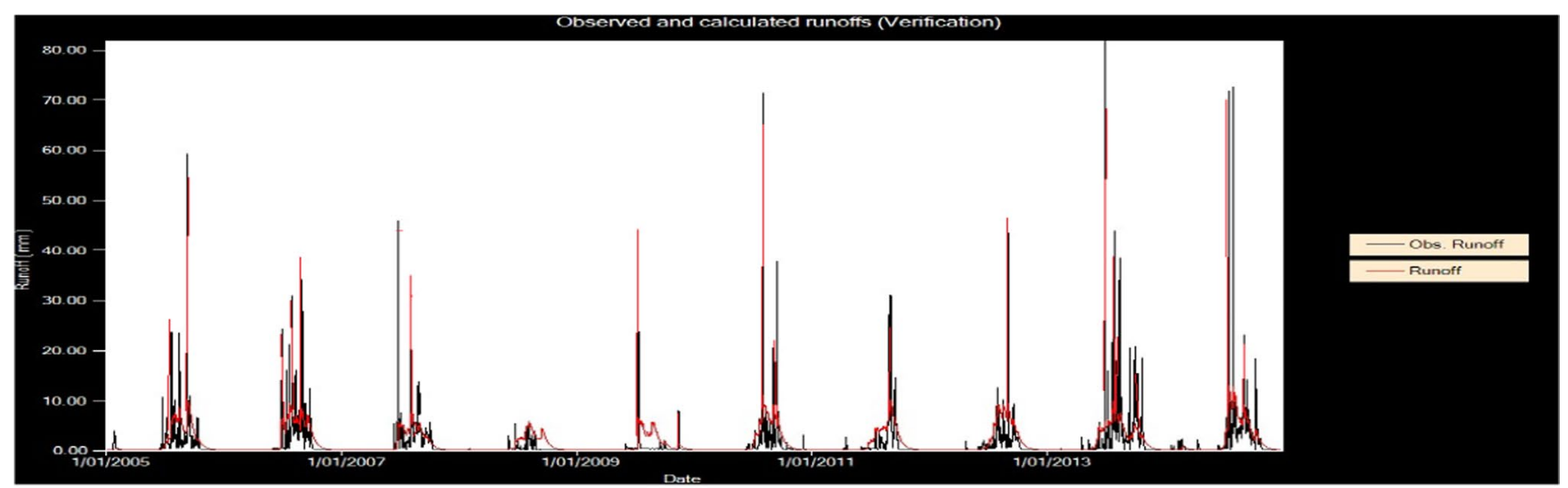

(b) Validation

Fig. 5 Observed and simulated runoff from AWBM 


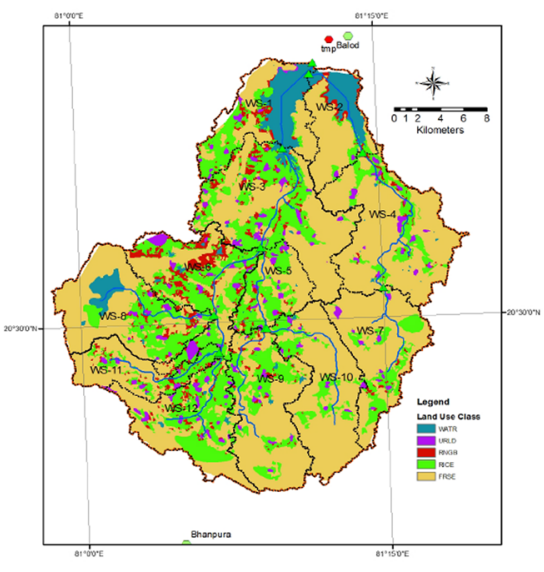

(a) Land use

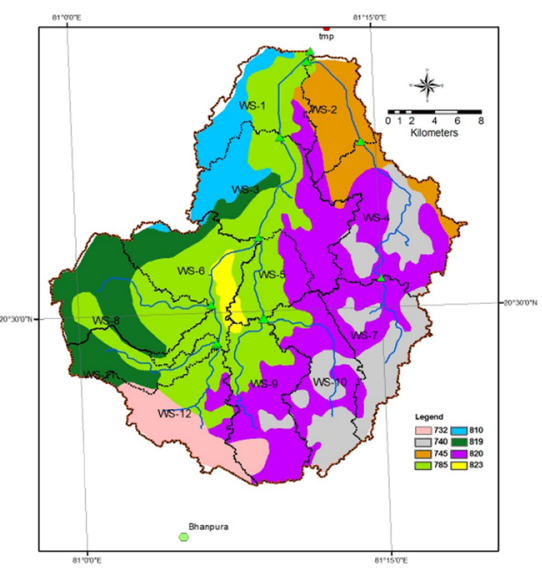

(b) Soil map

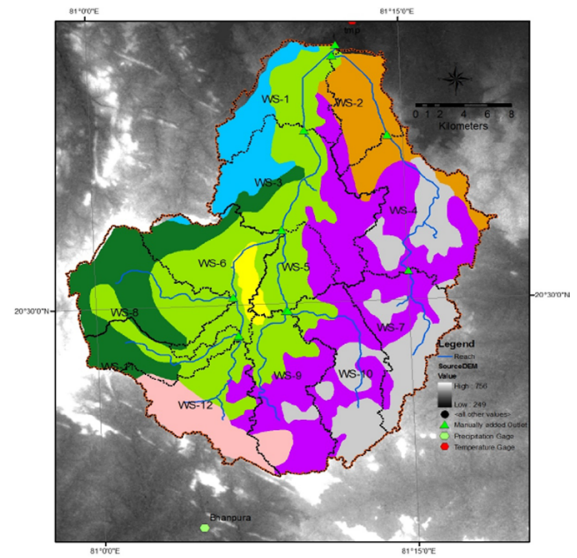

(c) DEM and SWAT setup

Fig. 6 Land use, soil and SWAT set-up for Tandula catchment

Table 6 Results of sensitivity, calibration and validation of SWAT model

\begin{tabular}{|c|c|c|c|c|c|}
\hline \multirow[t]{2}{*}{ Parameter name } & \multirow[t]{2}{*}{ Description of parameter } & \multicolumn{2}{|c|}{ Sensitivity results } & \multicolumn{2}{|c|}{ Calibration and validation results } \\
\hline & & $t$ stat & $P$ value & Best value & Range \\
\hline R_CN $\mathrm{CN}_{2}$ & SCS curve number & -14.429 & 0.00 & -0.015 & -0.1226 to 0.0927 \\
\hline Sol_k & Saturated hydraulic conductivity & -13.648 & 0.00 & 0.748 & 0.0267 to 1.5227 \\
\hline Sol_AWC & Soil antecedent water content & -1.449 & 0.015 & 0.058 & -0.3133 to 0.4293 \\
\hline$C h \_N 2$ & Manning's $N$ for main channel & -1.341 & 0.018 & 0.032 & 0.001 to 0.1662 \\
\hline Alpha_bf & Base flow alpha factor & -0.988 & 0.032 & 0.514 & 0.2567 to 0.7713 \\
\hline ESCO & Soil evaporation compensation factor (days) & -0.914 & 0.036 & 0.773 & 0.3858 to 1.1591 \\
\hline$G W Q M N$ & $\begin{array}{l}\text { Threshold depth in the shallow aquifer required } \\
\text { for return flow to occur (mm) }\end{array}$ & -0.676 & 0.050 & 33.75 & о 2268.801 \\
\hline
\end{tabular}

The comparison of observed and simulated runoff during calibration and validation has been presented in Fig. 7; from the analysis, it has been found that Nash-Sutcliffe efficiency of SWAT model was worked out as 0.75 during calibration and 0.65 during validation.

In the study, two conceptual (AWBM and TANK) and a physical semi-distributed (SWAT) models were applied in a basin. These models contain a sperate set of parameters and optimization technique. The performance of these models was evaluated on the basis of some standard goodness-of-fit criterions including root-mean-square error, the coefficient of correlation, Nash-Sutcliffe efficiency and coefficient of determination, etc. The best-fit criterions for calibration and validation of different models are presented in Table 7.

The efficiency criteria of different models during calibration and validation indicated a satisfactory performance of all these models used in the study. From the analysis, it has been found that RRL TANK model performed comparatively better in both calibration and validation, while SWAT model due to its complexity, multiple spatially distributed information and climatic data performed with the lowest efficiency. As SWAT model has several parameters to depict hydrological processes above and below the earth, sometime could not be optimized and gave less efficiency. However, due to incorporation of land use, slope, soil and climatic data, the SWAT model can be used for impact assessment of land use change and climate change assessment in a basin.

\section{Conclusions}

The multi models' approach is preferred in hydrological modelling due to inherent multiple uncertainties in processes, input, output, etc. In the present study, two conceptual and one physically semi-distributed model have been applied in a basin where runoff data were determined by the water balance of the reservoir. The analysis suggested that the RRL TANK model performed better than the AWBM and the SWAT model used in the analysis. The performance of SWAT model is the lowest among all the models used in the study; however, use of spatially 


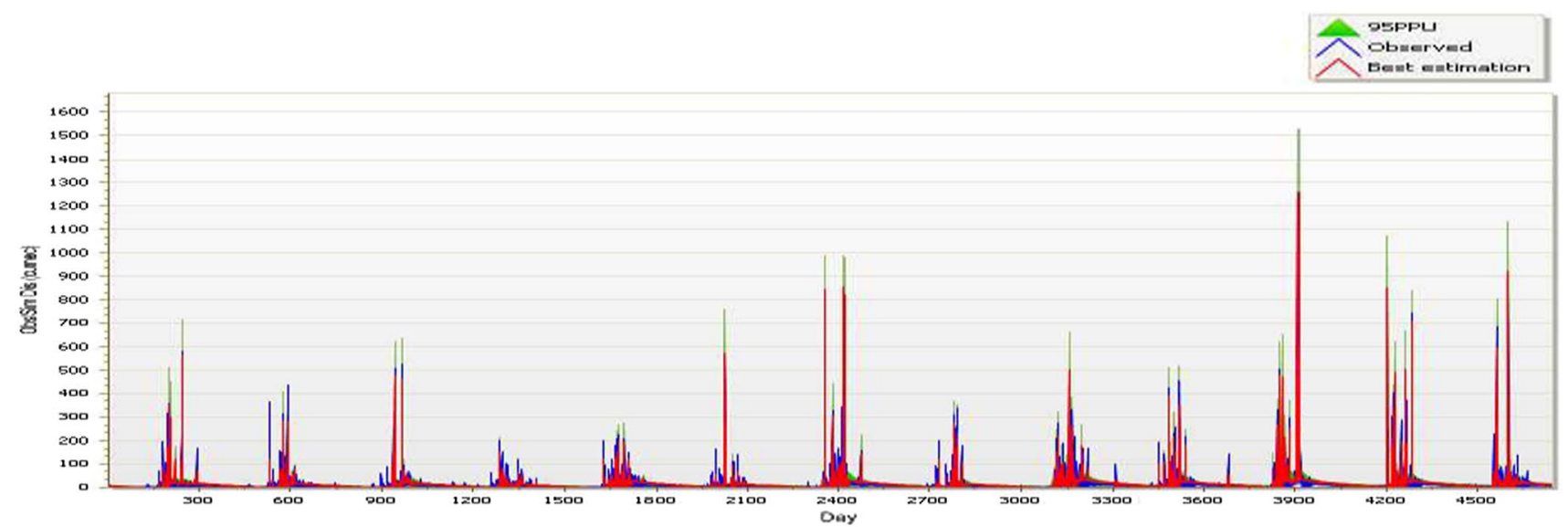

(a) Calibration

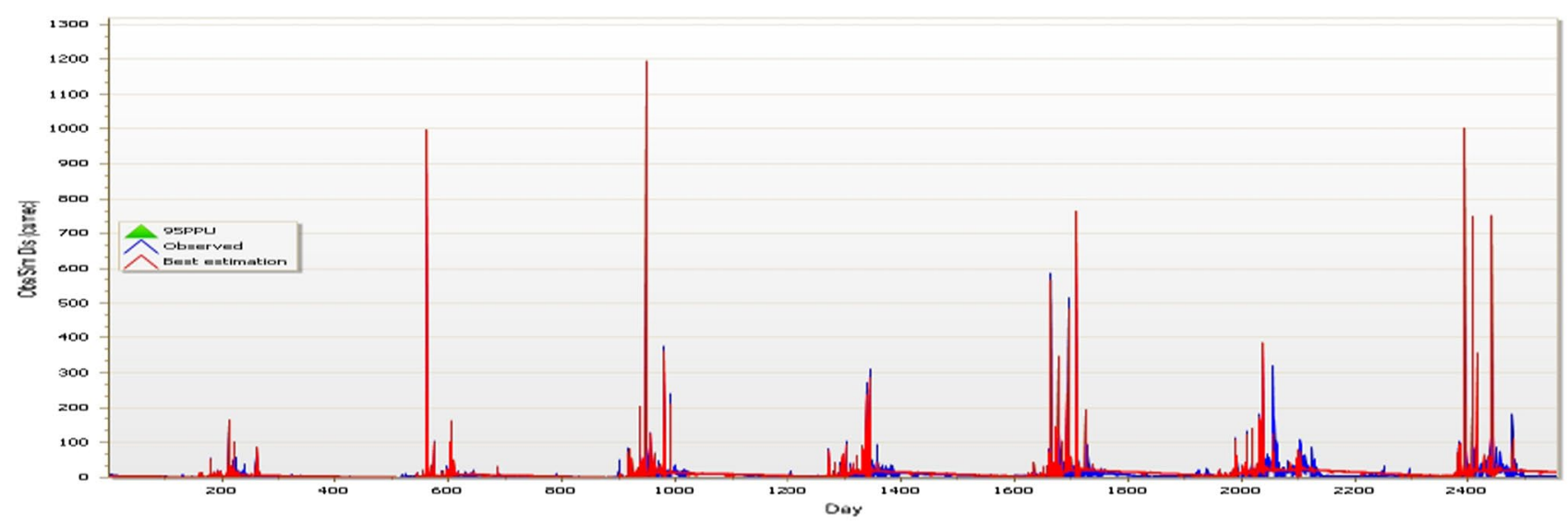

(b) Validation

Fig. 7 Observed and simulated from SWAT model

Table 7 Goodness-of-fit criterions during calibration and validation of different models

\begin{tabular}{|c|c|c|c|c|c|c|}
\hline \multirow[t]{2}{*}{ Goodness of fit criteria } & \multicolumn{2}{|l|}{ AWBM } & \multicolumn{2}{|c|}{ TANK model } & \multicolumn{2}{|c|}{ SWAT model } \\
\hline & Calibration & Validation & Calibration & Validation & Calibration & Validation \\
\hline Root-mean-square error & 129.57 & 170.60 & 122.60 & 155.60 & - & - \\
\hline Coefficient of determination & 0.79 & 0.75 & 0.81 & 0.61 & 0.76 & 0.81 \\
\hline Nash-Sutcliffe efficiency & 0.76 & 0.79 & 0.84 & 0.81 & 0.75 & 0.65 \\
\hline Coefficient of correlation & 0.88 & 0.86 & 0.90 & 0.78 & 0.79 & 0.76 \\
\hline
\end{tabular}

distributed information of landforms, soil, topography and climate data make this model capable of assessing the impact of land use, climate change and management practices applied in the basin. The model set-up of the conceptual model is easy in RRL, whereas SWAT model requires more spatial data and computational time. The model setup in the conceptual model is limited to the single basin and single outlet; however, modelling in SWAT can be done with multiple sub-watersheds and outlets in a basin.
The TANK model performs slightly better than AWBM ; however, calibration and validation of this model took more time and effort due to a large number of parameters.

Acknowledgements Authors are thankful to the Water Resources Department, Govt. of Chhattisgarh (India), and Indira Gandhi Krishi Vishwavidyalaya, Raipur, for providing data for the study. 


\section{Compliance with ethical standards}

Conflict of interest The authors declare that they have no conflict of interest.

Ethical approval All the authors and source have been duly recognized.

Open Access This article is licensed under a Creative Commons Attribution 4.0 International License, which permits use, sharing, adaptation, distribution and reproduction in any medium or format, as long as you give appropriate credit to the original author(s) and the source, provide a link to the Creative Commons licence, and indicate if changes were made. The images or other third party material in this article are included in the article's Creative Commons licence, unless indicated otherwise in a credit line to the material. If material is not included in the article's Creative Commons licence and your intended use is not permitted by statutory regulation or exceeds the permitted use, you will need to obtain permission directly from the copyright holder. To view a copy of this licence, visit http://creativecommons.org/licenses/by/4.0/.

\section{References}

Abbott MB, Bathurst JC, Cunge JA, O'Connell PE, Rasmussen J (1986a) An introduction to the European Hydrological SystemSystem eHydrologique European, 'SHE', 1: history and philosophy of a physically based distributed modelling system. J Hydrol $87: 45-59$

Abbott MB, Bathurst JC, Cunge JA, O'Connell PE, Rasmussen J (1986b) An introduction to the European Hydrological SystemSysteme Hydrolog ique Europeen 'SHE'. 2: structure of a physically based, distributed modelling system. J Hydrol 87:61-77

Arnold JG, Allen PM, Bernhardt G (1993) A comprehensive surface \& groundwater flow model. J Hydrol 142:47-69

Arnold JG, Srinivasan R, Muttiah RS, Williams JR (1998a) Large area hydrologic modelling and assessment. Part I-model development. J Am Water Resour Assoc 34(1):73-89

Arnold JG, Srinivasan R, Muttiah RS, Williams JR (1998b) Large area hydrologic modelling and assessment. Part II. Model development. J Am Water Resour Assoc 34(1):91-101

Bandaragoda C, Tarboton DG, Woods R (2004) Application of TOPNET in the Distributed Model Intercomparison Project. J Hydrol 298(1-4):178-201

Beck MB, Kleissenand FM, Wheater HS (1990) Identifying flow paths in models of surface water acidification. Rev Geophys 28:207-230

Bergstrom S (1992) The HBV model-its structure and applications. SMHI Hydrology, RH No. 4, Sweden, Norrkoping

Bergstrom S (1995) The HBV model. In: Singh VP (ed) Computer models of watershed hydrology. Water Resources Publications, Highlands Ranch, pp 443-476

Beven KJ, Kirkby MJ (1976) Towards a simple physically based variable contributing model of catchment hydrology. Working Paper 154, University of Leeds, UK, Leeds

Beven KJ, Kirkby MJ (1979) A physically based variable contributing area model of basin hydrology. Hydrol Sci Bull 24(1):43-69

Beven K, Lamb R, Quinn P, Romanowicz R, Freer J (1995) TOPMODEL. In: Singh VP (ed) Computer models of watershed hydrology. Water Resources Publications, Highlands Ranch, pp 627-668

Biftu GF, Gan TY (2001) Semi-distributed, physically based, hydrologic modelling of the Paddle River Basin, Alberta using remotely sensed data. J Hydrol 244:137-156
Biftu GF, Gan TY (2004) Semi-distributed, hydrologic modelling of dry catchment with remotely sensed and digital terrain elevation data. Int J Remote Sen 25(20):4351-4379

Boughton WC (1984) A simple model for estimating the water yield of ungauged catchments. Civ Eng Trans Inst Eng Canberra CE26(2):83-88

Brazil LE, Hudlow MD (1981) Calibration procedures used with the national weather service river forecast system. In: Haimes YY, Kindler J (eds) Water and related land resource systems. Pergamon Press, New York, pp 457-566

Burnash RJE, Ferral RL, McGuire RA (1973) A generalized streamflow simulation system. Joint Federal State River Forecast Centre, Sacramento

Chen Y, Li J, Xu H (2016) Improving flood forecasting capability of physically based distributed hydrological models by parameter optimization. Hydrol Earth Sys Sci. 20:375-392. https://doi. org/10.5194/hess-20-375

Chiew F, McMahon T (1994) Application of the daily rainfall runoff model MODHYDROLOG to 28 Australian catchments. J Hydrol 153:383-416

Clark CO (1945) Storage and the unit hydrograph. Trans Am Soc Civil Eng 110:1419-1488

Crawford NH, Linsley RK (1966) Digital simulation in hydrology: Stanford watershed model IV, Department of Civil Engineering Report 39, CA, USA

Glavan M, Pinter M (2012) Strengths, weaknesses, opportunities and threats of catchment modelling with soil and water assessment tool (SWAT) model. In: Nayak PC (ed) Water resources management and modelling. Intech Open, London, pp 39-62. https://doi.org/10.5772/34539

Haque MM, Rahman A, Hagare D, Kibria G (2015) Parameter uncertainty of the AWBM model when applied to an ungauged catchment. Hydrol Processes 29(6):1493-1504

Hargreaves GL, Hargreaves GH, Riley JP (1985) Agricultural benefits for Senegal river basin. J Irrig Drain Eng 111(2):113-124

Hooghoudt SB (1940) Bijdrage tot de kennis van enge naturrkundige goortheden van de grond. Versl Landbouwkd Ondrez 46:515-707

Jiang T, Chen YQ, Xu CY, Chen XH, Chen X, Singh VP (2007) Comparison of hydrological impacts of climate change simulated by six hydrological models in the Dongjiang Basin, South China. J Hydrol 336:316-333

Kar AK, Lohani AK, Goel NK, Roy GP (2015) Rain gauge network design for flood forecasting using multi-criteria decision analysis and clustering techniques in lower Mahanadi river basin. India $\mathbf{J}$ Hydrol: Regional Stud 4(Part B):313-332

Kar AK, Lohani AK, Goel NK, Roy GP (2017) Development of a fuzzy flood forecasting model for downstream of Hirakud Reservoir of Mahanadi Basin, India. In: Sharma N (ed) River system analysis and management. Springer, Singapore, pp 211-218

Kerkhoven E, Gan TY (2006) A modified ISBA surface scheme for modelling the hydrology of Athabasca river basin with GCMscale data. Adv Water Resour 29:808-826

Khoi DN, Thom VT (2015) Parameter uncertainty analysis for simulating streamflow in a river catchment of Vietnam. Global Ecol Conserv 4:538-548

Kite GW (1995) The SLURP model. In: Singh VP (ed) Computer models of watershed hydrology. Water Resources Publications, Highlands Ranch, pp 521-562

Klaus J, Zehe E (2010) Modelling rapid flow response of a tile-drained field site using a $2 \mathrm{D}$ physically based model: assessment of 'equifinal' model setups. Hydrol Process 24:1595-1609

Kokkonen TS, Jakeman AJ (2001) A comparison of metric and conceptual approaches in rainfall-runoff modeling and its implications. Water Resour Res 37(9):2345-2352 
Kumar A, Singh R, Jena PP, Chatterjee C, Mishra A (2015) Identification of the best multi-model combination for simulating river discharge. J Hydrol 525:313-325

Leavesley GH (1994) Modeling the effects of climate change on water resources: A review. Clim Change 28:159-177

Liang GC, O'Connor KM, Kachroo RK (1994) A multiple-input, single-output, variable gain-factormodel. J Hydrol 155:185-198

Loague K (2010) Benchmark papers in hydrology, vol 4. IAHS press, Wallingford

Lohmann D, Raschke E, Nijssen B, Lettenmaier DP (1998) Regional scale hydrology: I. Formulation of the VIC-2L model coupled to a routing model. J Hydrol 43:131-141

Mamo HMM, Jain MK (2013) Runoff and sediment modeling using SWAT in Gumera catchment, Ethiopia. Open J Mod Hydrol 3:196-205

Monteith JL (1965) Evaporation and the environment. In: 19th symposia of the society of experimental biology. Cambridge University Press, London, pp 205-234

Moore RJ (1985) The probability-distributed principle and runoff production at point and basin scales. Hydrol Sci J 30(2):273-297

Moriasi DN, Arnold JG, Van Liew MW, Bingner RL, Harmel RD, Veith TL (2007) Model evaluation guidelines for systematic quantification of accuracy in watershed simulations. Trans Am Soc Agric Biol Eng 50:885-900

Nash J (1957) The form of the instantaneous unit hydrograph, vol 59. IAHS Press, Wallingford, pp 202-213

Nash JE, Sutcliffe JV (1970) River flow forecasting through conceptual models, Part 1-a discussion of principles. J Hydrol 10:282-290

Neitsch SL, Arnold JG, Kiniry JR, Willams JR (2001) Soil and water assessment tool—manual. USDA-ARS Publications, USA. http:// www.brc.tamus.edu/swat/manual. Accessed 24 Mar 2019

Neitsch SL, Arnold JG, Kiniry JR, Srinivasan R, Williams JR (2002) Soil and water assessment tool: user's manual version 2000. Texas Water Resources Institute, TR-192, Texas

Neitsch SL, Arnold JG, Kiniry JR, Srinivasan R, Williams JR (2005) Soil and water assessment toolinput/output file documentation, version 2005. Grassland Soil and Water Research Laboratory, Texas

Nolihan J, Mahfouf J (1996) ISBA land surface parameterization scheme. Glob Planet Change 13:145-159

Nolihan J, Planton S (1989) A simple parameterization of land surface processes for meteorological models. Mon Weather Rev 117(3):536-542

Onyutha C (2016) Influence of hydrological model selection on simulation of moderate and extreme flow events: a case study of the blue Nile basin. Adv Meteorol. https://doi.org/10.1155/2016/7148326

Praskievicz S, Chang H (2009) A review of hydrological modelling of basin-scale climate change and urban development impacts. Prog Phys Geog 33:650-671

Priestley CHB, Taylor RJ (1972) On the assessment of surface heat flux and evaporation using large-scale parameters. Mon Weather Rev 100:81-92

Qu Y, Duffy CJ (2007) A semi discrete finite volume formulation for multiprocess watershed simulation. Water Resour Res 43:W08419. https://doi.org/10.1029/2006wr005752

Refsgaard JC, Storm B (1995) MIKE SHE. In: Singh VP (ed) Computer models of watershed hydrology. Water Resources Publications, Highlands Ranch, pp 809-846

Ritchie JT (1972) Model for predicting evaporation from a row crop with incomplete cover. Water Resour Res. https://doi.org/10.1029/ WR008i005p01204

Santhi C, Srinivasan R, Arnold JG, Williams JR (2006) A modeling approach to evaluate the impacts of water quality management plans implemented in a watershed in Texas. Environ Model Soft 21(8):1141-1157

Sherman LK (1932) Streamflow from rainfall by the unit-hydrograph method. Eng News Rec 108:501-505
Shoaib M, Shamseldin AY, Khan S, Khan MM, Khan ZM, Melville BW (2018) A wavelet based approach for combining the outputs of different rainfall-runoff models. Stoch Environ Res Risk Assess 32(1):155-168

Sugawara M, Ozaki E, Watanabe L, Katsuyama S (1974) Tank model and its application to Bird Creek, Wollombi Brook, Bikin river, Kitsu river, Sanaga river and Nam mune. Research note of the National Research Center for Disaster Prevention, Science and Technology Agency, Tokyo

Sugawara MI, Watanabe I, Ozaki E, Katsuyame Y (1983) Reference manual for the TANK model. National Research Center for Disaster Preview, Tokyo

Tamgadge DB, Gajbhtye KS, Bankar WV (2002) Evaluation of soil suitability for paddy cultivation in Chhattisgarh-a parametric approach. J Indian Soc Soil Sci 50:81-88

Therrien R, McLaren R, Sudicky EA, Panday S (2006) HydroGeoSphere: a three-dimensional numerical model describing fullyintegrated subsurface and surface flow and solute transport. Groundwater Simulation Group, University of Waterloo, Waterloo

Todini E (1996) The ARNO rainfall-runoff model. J Hydrol 175:339-382

Uniyal B, Jha MK, Verma AK (2015) Parameter identification and uncertainty analysis for simulating stream flow in a river basin of eastern India. Hydrol Process 29(17):3744-3766

Vaze J, Jordan P, Beecham R, Frost A, Summerell G (2012) Guidelines for rainfall-runoff modeling-towards best practice model application. Water Research Cooperation, Bruce, ACT

Wang XL, Swail VR, Cox A (2010) Dynamical versus statistical downscaling methods for ocean wave heights. Int J Climatol 30:317-332

Wang J, Yang H, Li L, Gourley JJ, Sadiq IK, Yilmaz KK, Adler RF, Policelli FS, Habib S, Irwn D, Limaye AS, Korme T, Okello L (2011) The coupled routing and excess storage (CREST) distributed hydrological model. Hydrol Sci J 56(1):84-98

Wood EF, Lettenmaier DP, Zatarian VGA (1992) Land-surface hydrology parameterisation with sub-grid variability for general circulation models. J Geophys Res 97(D3):2717-2728

$\mathrm{Wu} \mathrm{H}$, Chen B (2015) Evaluating uncertainty estimates in distributed hydrological modeling for the Wenjing River watershed in China by GLUE, SUFI-2, and ParaSol methods. Ecol Eng 76:110-121. https://doi.org/10.1016/j.ecoleng.2014.05.014

Yang J, Reichert P, Abbaspour KC, Xia J, Yang H (2008) Comparing uncertainty analysis techniques for a SWAT application to the Chaohe Basin in China. J Hydrol 358:1-23

Yang H, Wang G, Yang Y, Xue B, Wu B (2014) Assessment of the impacts of land use changes on nonpoint source pollution inputs upstream of the Three Gorges Reservoir. Sci World J. https://doi. org/10.1155/2014/526240

Zehe E, Becker R, Bardossy A, Plate E (2005) Uncertainty of simulated catchment sale runoff response in the presence of threshold processes: role of initial soil moisture and precipitation. J Hydrol 315:183-202

Zhang Q, Liu J, Singh VP, Gu X, Chen X (2016) Evaluation of impacts of climate change and human activities on streamflow in the Poyang lake basin, China. Hydrol Process 30(14):2562-2576

Zhao RJ, Liu XR (1995) The Xinanjiang model. In: Singh VP (ed) Computer models of watershed hydrology. Water Resource Publications, Highlands Ranch, pp 215-232

Publisher's Note Springer Nature remains neutral with regard to jurisdictional claims in published maps and institutional affiliations. 